\title{
45. MAGNETIC PROPERTIES OF BASALTS AND SEDIMENTS FROM THE LAU BASIN ${ }^{1}$
}

\author{
Niels Abrahamsen ${ }^{2}$ and William W. Sager ${ }^{3}$
}

\begin{abstract}
Paleomagnetic and rock-magnetic investigations of basalts from Hole 834B in the Lau backarc basin and of sediments from Holes $841 \mathrm{~A}$ and $841 \mathrm{~B}$ at the Tonga Ridge are reported. Three groups of blocking temperatures in the basalts suggest the presence of at least three magnetic phases: pure magnetite, a Ti-poor titanomagnetite, and a Ti-rich phase. The drill-string-induced remanence in the basalts is typically between three and six times the original normal remanent magnetization intensity, but it is mostly removed by alternating-field (AF) cleaning in $5 \mathrm{mT}$. Volume susceptibility values range from $0.04 \times 10^{-3}$ to $4 \times 10^{-3} \mathrm{cgs}$. The modified $Q$-ratio $J_{5} /$ sus ranges from 0.5 to 10 .

The drill-string-induced remanence behaves different in the two sediment cores from Holes $841 \mathrm{~A}$ and $841 \mathrm{~B}$, which may be the result of differences in the sediment or caused by the different drilling equipment used.

The AF-cleaned inclinations of the sediment in Holes 841A and 841B suggest a slight flattening with increasing depth (up to $6^{\circ}$ under a load of $400 \mathrm{~m}$ of sediment) to be present. This flattening is likely to be caused by the differential rotation of detrital particles under compaction during diagenesis.
\end{abstract}

\section{INTRODUCTION}

In this paper we present detailed data from basaltic cores drilled in the Lau Basin (Holes 834B and 835B) and from sediments obtained from the Tonga Ridge (Holes $841 \mathrm{~A}$ and $841 \mathrm{~B}$ ). The area is a young (< ca. $5 \mathrm{Ma}$ ) and quite intensely studied backarc basin (Parson, Hawkins, Allan, et al., 1992) situated in the western south central Pacific, between the remnant arc of the Lau Ridge and the Tonga Arc between $18^{\circ}-22^{\circ} \mathrm{S}$ and $176^{\circ}-178^{\circ} \mathrm{W}$ (Fig. 1).

\section{SAMPLING AND MEASUREMENTS}

Shipboard pass-through cryogenic magnetic measurements were made on archive halves of the sediment cores, as well as on basalt cores and cubes. After having measured the natural remanent magnetization (NRM), they were stepwise partially demagnetized in alternating magnetic fields of up to $15 \mathrm{mT}$ and remeasured, as explained in Parson, Hawkins, Allan, et al. (1992, "Explanatory Notes" chapter).

A number of sediment cubes were also collected and measured in the shipboard cryogenic magnetometer (Holes 841A and 841B), whereas basalt minicores from Holes $834 \mathrm{~B}$ and $835 \mathrm{~B}$ were measured on land in a Molspin spinner magnetometer, undergoing partial stepwise AF demagnetization in small steps of $2.5 \mathrm{mT}$. In about half of the cases (see Table 1), the basalt cubes were thermally cleaned afterward in a magnetically shielded Schonstedt furnace. The volume susceptibility was also measured by means of a Geofyzika Microkappameter KT-5.

\section{RESULTS}

The rock-magnetic and paleomagnetic properties of the Lau Basin and Tonga Ridge sediments and volcanics, as measured onboard the JOIDES Resolution, are described in detail elsewhere (Parson, Hawkins, Allan, et al., 1992; Abrahamsen and Sager, this volume; Sager et al., this volume).

\footnotetext{
'Hawkins, J., Parson, L., Allan, J., et al., 1994. Proc. ODP, Sci. Results, 135: College Station, TX (Ocean Drilling Program).

${ }^{2}$ Department of Earth Sciences, Aarhus University, Finlandsgade 8, DK-8200 Aarhus N, Denmark.

${ }^{3}$ Departments of Oceanography and Geophysics, Texas A\&M University, College Station, TX 77843, U.S.A.
}

\section{Basalts}

The inferred blocking temperatures that resulted from the thermomagnetic cleaning of the basalt cubes are shown in Figure 2, based on values from Table 1. The blocking temperatures were estimated from the thermal intensity-decay curves, which are shown in Figure 3.

The blocking temperatures in the basalts from Hole $834 \mathrm{~B}$ fall into three rather distinct groups: around $580^{\circ} \mathrm{C}$, around $500^{\circ} \mathrm{C}$, and around $250^{\circ} \mathrm{C} \pm 100^{\circ} \mathrm{C}$. This indicates the presence of at least three magnetic phases: pure magnetite, Ti-poor titanomagnetite, and a phase with rather low blocking temperatures, probably a more Ti-rich titanomagnetite (Creer et al., 1977).

The drill-string-induced remanence may be very strong and dominant, typically between three and six times the original NRM intensity of the basalts. As may be seen in the AF intensity-decay curves illustrated in Figure 4, however, a major part of the drill-stringinduced remanence appears to be removed by AF cleaning in $5 \mathrm{mT}$. This level of cleaning, therefore, seems to restore satisfactorily the original predrilling NRM intensity of most of the basalts.

Hence, to obtain a more realistic estimate of rock-magnetic characteristics, such as the median destructive field (mdf) and the modified $Q$-ratio $(Q=$ remanence/susceptibility), the remanence intensity after partial AF cleaning in a field of $5 \mathrm{mT}, J_{5}$, was applied in the calculation of the mdf and the modified Q-ratio. From Table 1, we can see that the modified $Q$-ratio $=J_{5} /$ sus ranges from 0.46 to 10.6 in the basalts.

Volume susceptibilities of the measured basalt cubes range from 0.04 to $4 \times 10^{-3} \mathrm{cgs}(\cdot 4 \pi \mathrm{SI})$. More extensive susceptibility data from whole-core measurements are given in the Initial Reports volume (Parson, Hawkins, Allan, et al., 1992).

\section{Sediments}

The remanent intensity of sediment cubes combined from Holes $841 \mathrm{~A}$ and $841 \mathrm{~B}$ vs. depth are shown in Figure 5. Open symbols indicate the NRM inclination, whereas solid symbols indicate the inclination after 20-mT AF demagnetization.

Above a level of ca. $50 \mathrm{mbsf}$, the NRM intensity is low (10 to 100 $\mathrm{mA} / \mathrm{m}$ ); between 50 and $230 \mathrm{mbsf}$ the NRM intensity is an order of magnitude higher (typically between 200 and $800 \mathrm{~mA} / \mathrm{m}$ ); and below this level lower values typically between 50 and $200 \mathrm{~mA} / \mathrm{m}$ are seen.

The behavior against AF demagnetization in $20 \mathrm{mT}$ is notably different above and below $170 \mathrm{mbsf}$ (Fig. 5). Above this level the decrease in intensity is close to a factor of 10 , indicating very low 


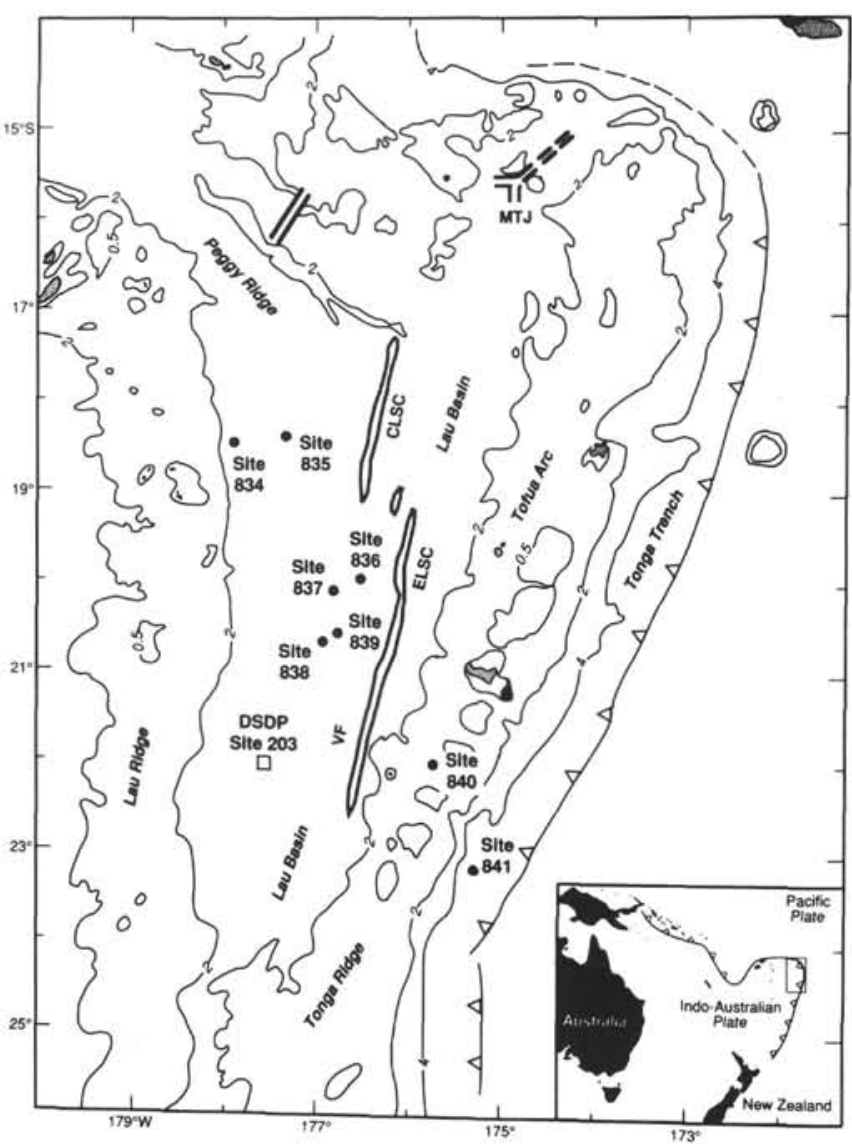

Figure 1. Index map of the Lau Ridge, Lau Basin, Tonga Ridge, Tofua Arc, and Tonga Trench, indicating the drill sites (834 through 841) of Leg 135. Central Lau and Eastern Lau spreading centers (CLSC and ELSC), Valu Fa Ridge (VF), and Mangatolu Triple Junction (MTJ) are also shown. Water depths in kilometers (from Leg 135 Scientific Party, 1991).

coercivity, whereas below 170 mbsf the decrease in intensity is only some $20 \%$ to $50 \%$.

The low intensity values above 50 mbsf compare with lithologic Unit I (Parson, Hawkins, Allan, et al., 1992), which is described as middle Pleistocene to ?Pliocene, structureless, grayish brown to greenish gray (between 0 and $17 \mathrm{mbsf}$ ) and light yellowish brown and greenish gray to dark greenish gray (between 17 and $55 \mathrm{mbsf}$ ) clays with very thin- to medium-bedded vitric sand, vitric silt, and coarse and fine ash interbeds. Late Miocene lithologic Unit II (56-333 mbsf) is described as interbedded black, dark greenish gray, and dark gray vitric siltstone, clay, clayey siltstone, vitric siltstone, and vitric sandstone (between 81 and $187 \mathrm{mbsf}$ ), and as vitric sandstones and vitric siltstones (between 170 and 333 mbsf); this part generally coarsens downward. The strong contrasts in NRM values and coercivity are probably caused by variations in the ash content as well as in the grain size of the sediment.

In Figure 6 the inclination of sediment cubes from Holes 841 A and $841 \mathrm{~B}$ are shown before (open symbols) and after (solid symbols) 20-mT AF demagnetization, respectively. Above $170 \mathrm{mbsf}$ the NRM inclination is steeply negative because of a dominating drill-stringinduced magnetization, which forced most inclinations into steep negative (updip) values. Below $170 \mathrm{mbsf}$ the drill-string-induced magnetization is less dominant; especially below ca. 300 mbsf, scattered values of original positive inclinations have survived in the NRM. Thus, the drill-string-induced remanence behaves differently in the sediment cores from Hole 841A and 841B. The reason for this may be the result of differences in the sediment, or it could be caused by differences in the magnetic properties of the drilling equipment

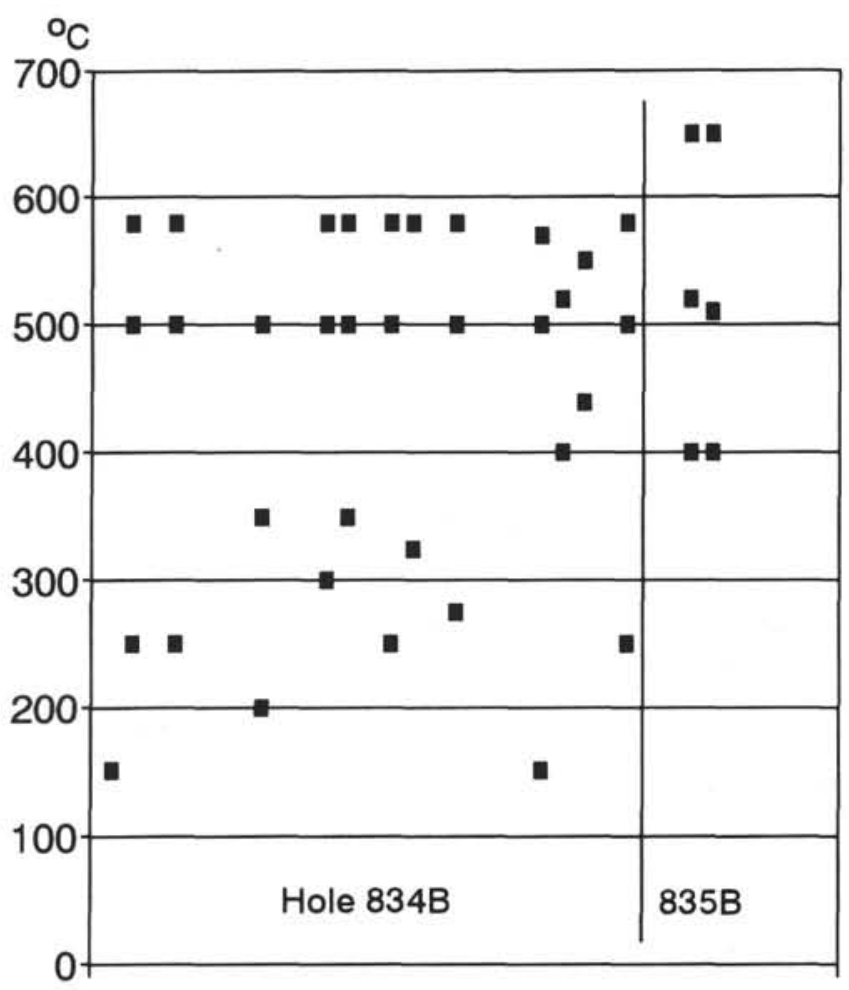

\section{Sample no. (arbitrary)}

Figure 2. Distribution of blocking temperatures in basalts from Holes 834B and $835 \mathrm{~B}$.

used, the cores of Hole 841A being of the $\mathrm{H}$ - or X-type, whereas cores from Hole $841 \mathrm{~B}$ are of the R-type.

Several sources of uncontrolled inclination errors arising from incorrect measurements of grain size, compaction, bioturbation, and remagnetization are possible in the sediments (e.g., Gordon, 1990b; Abrahamsen, 1992). Arason and Levi (1990) found a progressive downcore shallowing of the remanent inclination (from $6^{\circ}$ to $8^{\circ}$ ) in a 120-m deep section (DSDP Site 578 in the northwest Pacific), of which only one-fourth could be explained by the northward translation of the Pacific Plate. The inclination shallowing corresponds to a $3 \%-4 \%$ decrease in the porosity. Sediment paleolatitudes in a study by Gordon (1990a) were also found to be systematically more northerly than those predicted by the reference apparent polar wander path, corresponding to inclinations shallower than expected.

To investigate the possible influence of sediment compaction upon the inclination, numerical values $\operatorname{Norm}\left(I_{20}\right)$ of the inclination $I_{20}$ (cf. Table 2) are shown in Figure 7. Numerical values are used because a shallowing effect by compaction will act in the same sense on both positive and negative inclinations (Abrahamsen, 1992). The inclinations are shown after AF cleaning in $20 \mathrm{mT}$ to avoid influence from the drill-string-induced magnetization. In the graph a seven-point moving average is also plotted (thin dotted line), as well as the regression line, $\operatorname{Norm}\left(I_{20}\right)=-0.0145 \cdot \operatorname{Depth}+41.5(N=134)$. The central axial dipole inclination at the site is $I_{o}=40.8^{\circ}$, which is close to the mean of the upper part of the section. A slight but systematic shallowing of the inclination with a depth of ca. $6^{\circ}$ of the top $400 \mathrm{~m}$ sediment thus appears to be present also in these cores, although the individual data points are very scattered. The inclination shallowing is probably caused by differential rotation of the detrital particles during compression and diagenesis, which takes place after the locking in of the depositional remanence.

To get an overall impression of the strong variations in the magnetic properties of the sediments at Site 841, the whole-core volume 
Table 1. Rock-magnetic properties of basalts from Holes 834B and 835B.

\begin{tabular}{|c|c|c|c|c|c|c|c|c|c|}
\hline $\begin{array}{l}\text { Core, section, } \\
\text { interval }(\mathrm{cm})\end{array}$ & $\begin{array}{l}\text { Depth } \\
\text { (mbsf) }\end{array}$ & $\begin{array}{l}\mathrm{T}_{\max } \\
\left({ }^{\circ} \mathrm{C}\right)\end{array}$ & $\begin{array}{c}\text { Blocking } \\
\text { temperature } \\
\left({ }^{\circ} \mathrm{C}\right)\end{array}$ & $\begin{array}{l}\text { AF maximum } \\
(\mathrm{mT})\end{array}$ & $\mathrm{J}_{\mathrm{o}}(\mathrm{mA} / \mathrm{m})$ & $\mathrm{J}_{5}(\mathrm{~mA} / \mathrm{m})$ & $\begin{array}{l}\text { mdf }(\mathrm{mT}) \\
\qquad\left(\mathrm{J}_{5} \rightarrow\right)\end{array}$ & $\begin{array}{l}\text { Susceptibility } \\
\left(\times 10^{-6} \mathrm{cgs}\right)\end{array}$ & $\mathrm{Q}\left(\mathrm{J}_{5} / \mathrm{Sus}\right)$ \\
\hline \multicolumn{10}{|l|}{$135-834 \mathrm{~B}-$} \\
\hline $8 \mathrm{R}-1,25$ & 126.30 & & 150 & $0-80$ & 2387 & 985 & 9.0 & 594 & 1.66 \\
\hline $8 \mathrm{R}-2,34$ & 127.60 & 650 & $250,500,580$ & $0-22$ & 1672 & 968 & 9.0 & 532 & 1.82 \\
\hline $10 \mathrm{R}-1,13$ & 145.40 & & & $0-80$ & 3706 & 567 & 9.0 & 1243 & 0.46 \\
\hline $10 \mathrm{R}-2,13$ & 147.45 & 650 & $250,500,580$ & $0-22$ & 2023 & 1197 & 9.0 & 360 & 3.33 \\
\hline $10 \mathrm{R}-3,31$ & 148.40 & & & $0-85$ & 4173 & 1458 & 7.5 & 522 & 2.79 \\
\hline $11 \mathrm{R}-2,137$ & 152.22 & & & $0-22$ & 179 & 279 & 10.0 & 500 & 0.56 \\
\hline $12 \mathrm{R}-1,33$ & 156.00 & & & $0-80$ & 2432 & 1959 & 6.0 & 512 & 3.83 \\
\hline $12 R-4,22$ & 159.20 & 650 & $200,350,500$ & & & & & 428 & \\
\hline $13 \mathrm{R}-1,40$ & 161.14 & & & & & & & 554 & \\
\hline $13 R-2,13$ & 162.40 & & & $0-80$ & 1115 & 1001 & 8.0 & 488 & 2.05 \\
\hline $15 \mathrm{R}-1,30$ & 175.66 & 650 & $300,500,580$ & $0-22$ & 3162 & 3243 & $>22.0$ & 324 & 10.01 \\
\hline $16 \mathrm{R}-1,8$ & 185.02 & 650 & $350,500,580$ & $0-22$ & 5823 & 4125 & 10.0 & 388 & 10.63 \\
\hline $20 \mathrm{R}-1,92$ & 214.50 & & & & & & & 36 & \\
\hline $24 \mathrm{R}-1,51$ & 233.37 & 650 & $250,500,580$ & & & & & 308 & \\
\hline $28 \mathrm{R}-1,141$ & 253.43 & 650 & 325,580 & $0-80$ & 2698 & 2343 & 8.0 & 296 & 7.92 \\
\hline $32 \mathrm{R}-1,50$ & 271.95 & & & & & & & 260 & \\
\hline $33 \mathrm{R}-2,58$ & 283.25 & 650 & $275,500,580$ & & & & & 382 & \\
\hline $35 \mathrm{R}-2,90$ & 293.15 & & & & & & & 76 & \\
\hline $41 \mathrm{R}-1,76$ & 334.73 & & & & & & & 212 & \\
\hline $43 \mathrm{R}-1,21$ & 344.18 & & & & & & & 188 & \\
\hline $48 \mathrm{R}-1,37$ & 368.52 & 650 & $150,500,570$ & & & & & 1592 & \\
\hline $51 R-1,136$ & 384.20 & 550 & 440.520 & & & & & 1706 & \\
\hline $54 \mathrm{R}-1,138$ & 398.53 & 550 & 440,550 & & & & & 1280 & \\
\hline $56 \mathrm{R}-2,75$ & 409.10 & & & & & & & 3800 & \\
\hline $59 \mathrm{R}-1,114$ & 432.08 & 650 & $250,500,580$ & & & & & 378 & \\
\hline \multicolumn{10}{|l|}{ 135-835B- } \\
\hline $7 \mathrm{R}-2,23$ & 180.22 & & & $0-70$ & 1321 & 1377 & 20 & 144 & 9.56 \\
\hline $7 \mathrm{R}-2,122$ & 181.27 & 650 & $400,520,650$ & & & & & 470 & \\
\hline $7 R-3,130$ & 182.95 & 650 & $400,510,650$ & & & & & 536 & \\
\hline
\end{tabular}

Notes: $\mathrm{J}_{0}=$ natural remanent magnetization intensity; $\mathrm{J}_{5}=$ remanent intensity after alternating-field $(\mathrm{AF})$ demagnetization at $5 \mathrm{mT}$; and $\mathrm{mdf}=\mathrm{median}$ destructive field, supposing $\mathrm{J}_{5}$ to be the original remanent intensity. Q $=$ modified Q-ratio based upon the value of $\mathrm{J}_{5}$.

susceptibilities for Holes 841A and 841B are also shown (Figs. 8-9). Susceptibility ranges over 2 orders of magnitude. The sediment properties therefore are highly variable, as may be expected in this environment, close to intensive volcanic activity with discrete eruption events. The strong variations in susceptibility are most likely caused by the highly fluctuating content of volcanic ash in the sediments.

\section{CONCLUSIONS}

We conclude that the blocking temperatures in the basalts investigated fall into three distinct groups: around $580^{\circ} \mathrm{C}$, around $500^{\circ} \mathrm{C}$, and about $250^{\circ} \mathrm{C} \pm 100^{\circ} \mathrm{C}$. This may suggest the presence of at least three magnetic phases: pure magnetite, Ti-poor titanomagnetite, and a phase with low blocking temperatures, probably Ti-rich titanomagnetite. Volume susceptibility values range from $0.04 \times 10^{-3}$ to $4 \times 10^{-3}$ cgs in the basalts. The modified $Q$-ratio $J_{5}$ /sus ranges from 0.5 to 10.0 .

Drill-string-induced remanence of the basalts may be as high as three to six times the original NRM intensity, but it was mostly removed by AF cleaning at $5 \mathrm{mT}$.

Drill-string-induced remanence behaves differently in the sediment cores from Hole $841 \mathrm{~A}$ and $841 \mathrm{~B}$. The reason for this may be the result of differences in the sediment or of differences in the drilling equipment used (H- or X-type in Hole 841A, in contrast to R-type in Hole 841B).

The inclination of the sediments in Holes $841 \mathrm{~A}$ and $841 \mathrm{~B}$ display a slight flattening with increasing depth (ca. $6^{\circ}$ under a load of $400 \mathrm{~m}$ of sediment). This flattening is likely to be a result of the differential rotations of the detrital particles under moderate compaction, which occurred during the diagenetic processes in the sediments that took place after the locking of the depositional remanence.

An inclination flattening in deep-sea sediments, amounting to several degrees of arc, as in the present case, may add up to significant and systematic errors in the paleolatitude and hence cause bias, if used in plate tectonic reconstructions.

\section{ACKNOWLEDGMENTS}

Part of the work was supported by a grant to N. Abrahamsen from the Danish Natural Science Foundation and to W.W. Sager by JOI/USSAC. We thank Anna Norberciak for assisting in the laboratory, and Marek Lewandowski for lending us his program for paleomagnetic data processing.

\section{REFERENCES $*$}

Abrahamsen, N., 1992. On farsidedness of palaeomagnetic poles: magnetic refraction, sediment compaction and dipole off-set. Stud. Geophys. Geod., $36: 26-41$.

Arason, P., and Levi, S., 1990. Compaction and inclination shallowing in deep-sea sediments from the Pacific Ocean. Eos, 71:381.

Creer, K.M., Hedley, I.G., and O'Reilly, W., 1977. Magnetic oxides in geomagnetism. In Craik, D.J. (Ed.), Magnetic Oxides: London (Wiley), 649-688.

Gordon, R.G., 1990a. Paleomagnetically determined paleolatitudes from $\mathrm{Pa}$ cific Plate Deep Sea Drilling Project sediments. Eos, 71:381. , 1990b. Test for bias in paleomagnetically determined paleolatitudes from Pacific Plate Deep Sea Drilling Project sediments. J. Geophys. Res., 95:8397-8408.

Leg 135 Shipboard Science Party, 1991. A new view of ARC/BACKARC systems. Geotimes, 36:19-20.

Parson, L., Hawkins, J., Allan, J., et al., 1992. Proc. ODP, Init. Repts., 135: College Station, TX (Ocean Drilling Program).

Date of initial receipt: 6 July 1992

Date of acceptance: 4 January 1993

Ms 135SR-121

- Abbreviations for names of organizations and publication titles in ODP reference lists follow the style given in Chemical Abstracts Service Source Index (published by American Chemical Society). 


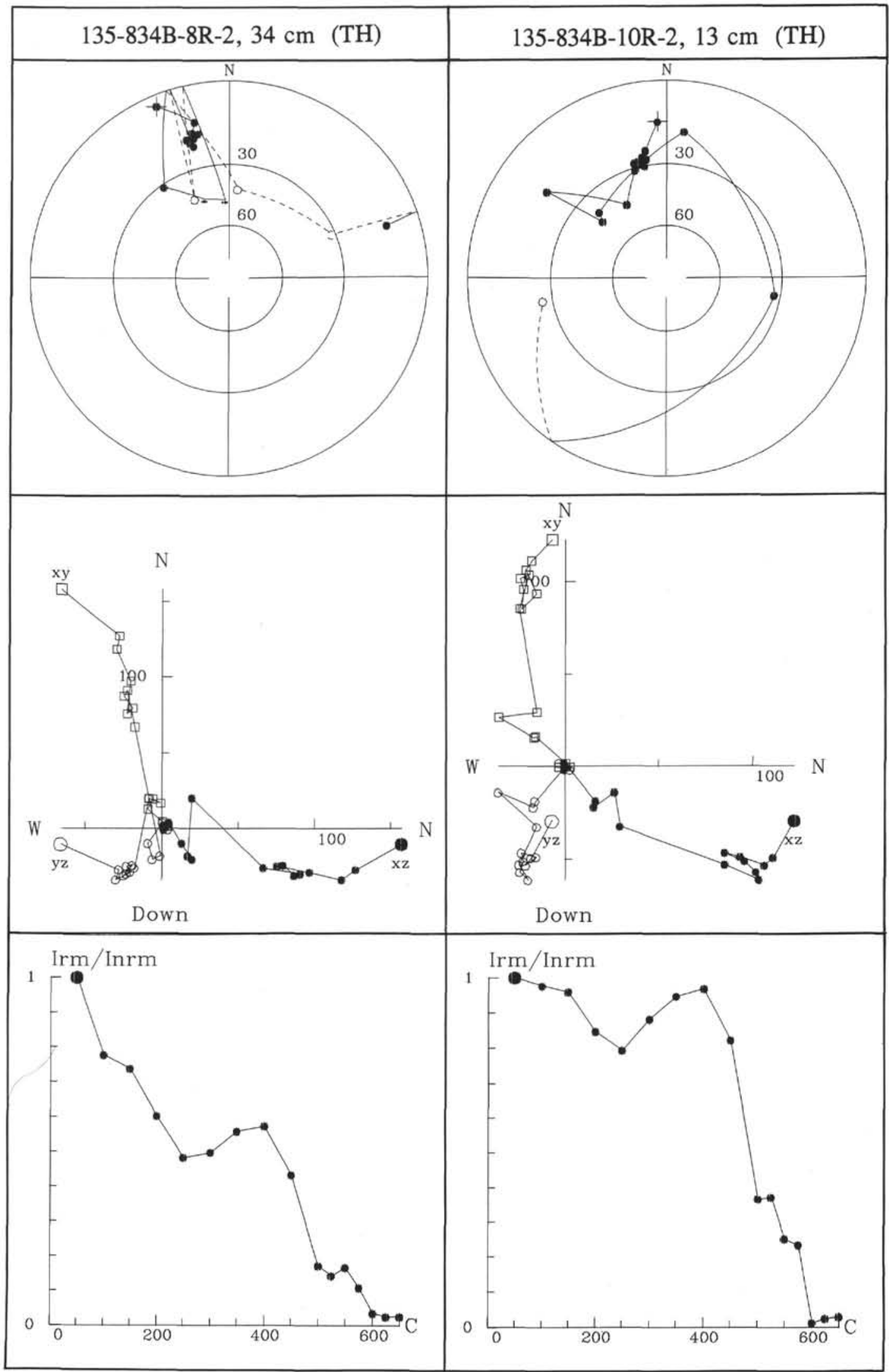

Figure 3. Thermal demagnetization (TH) of 12 basalt samples from Hole 834B and 2 basalt samples from Hole $835 \mathrm{~B}$. Stereograms (top), orthogonal plots (middle part), and intensity-decay curves (base) are illustrated. Four of the samples were partly AF demagnetized in $22 \mathrm{mT}$, and one in $80 \mathrm{mT}$, before thermal demagnetization was undertaken (see Table 1). 


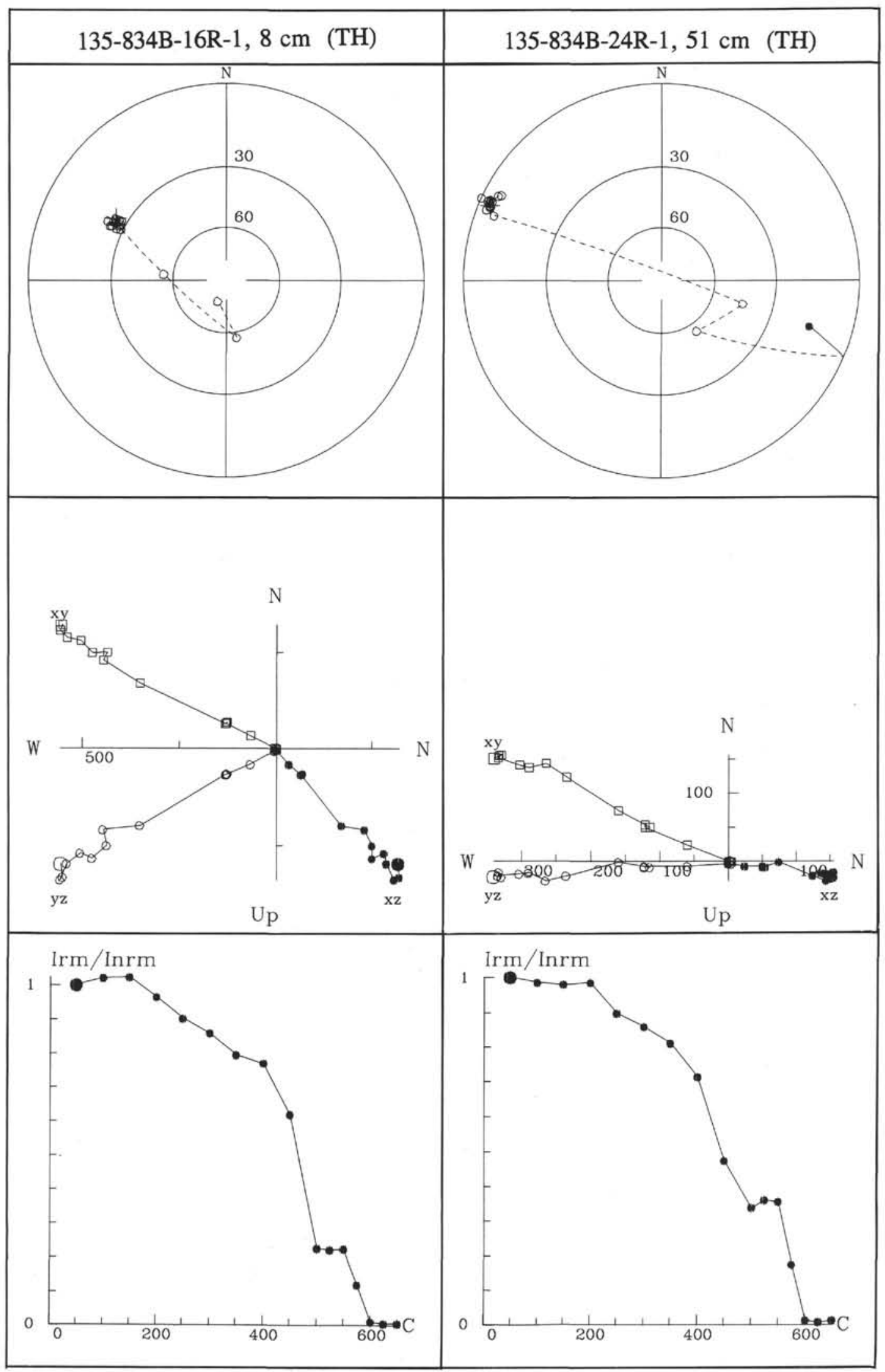

Figure 3 (continued). 


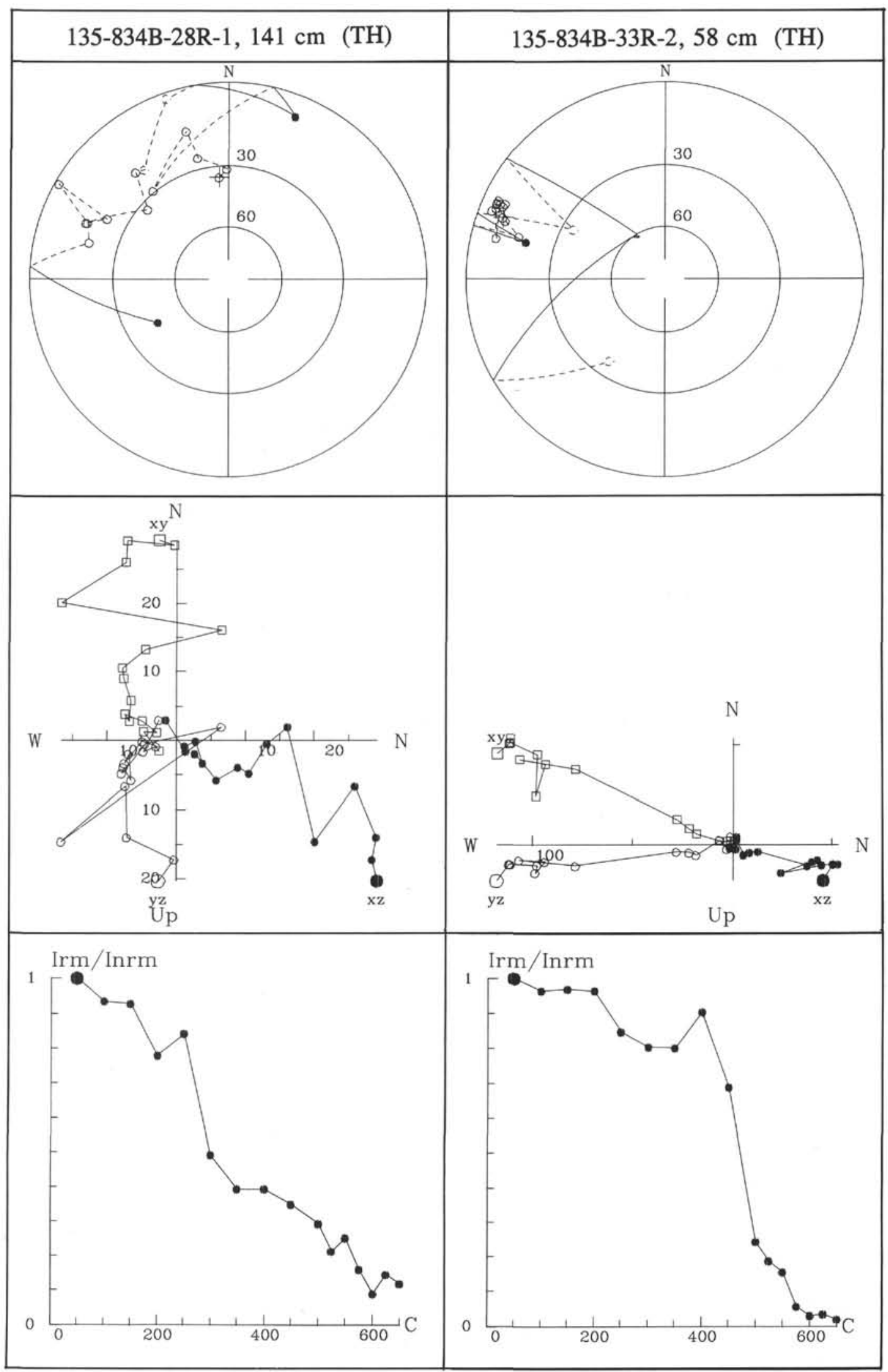

Figure 3 (continued). 


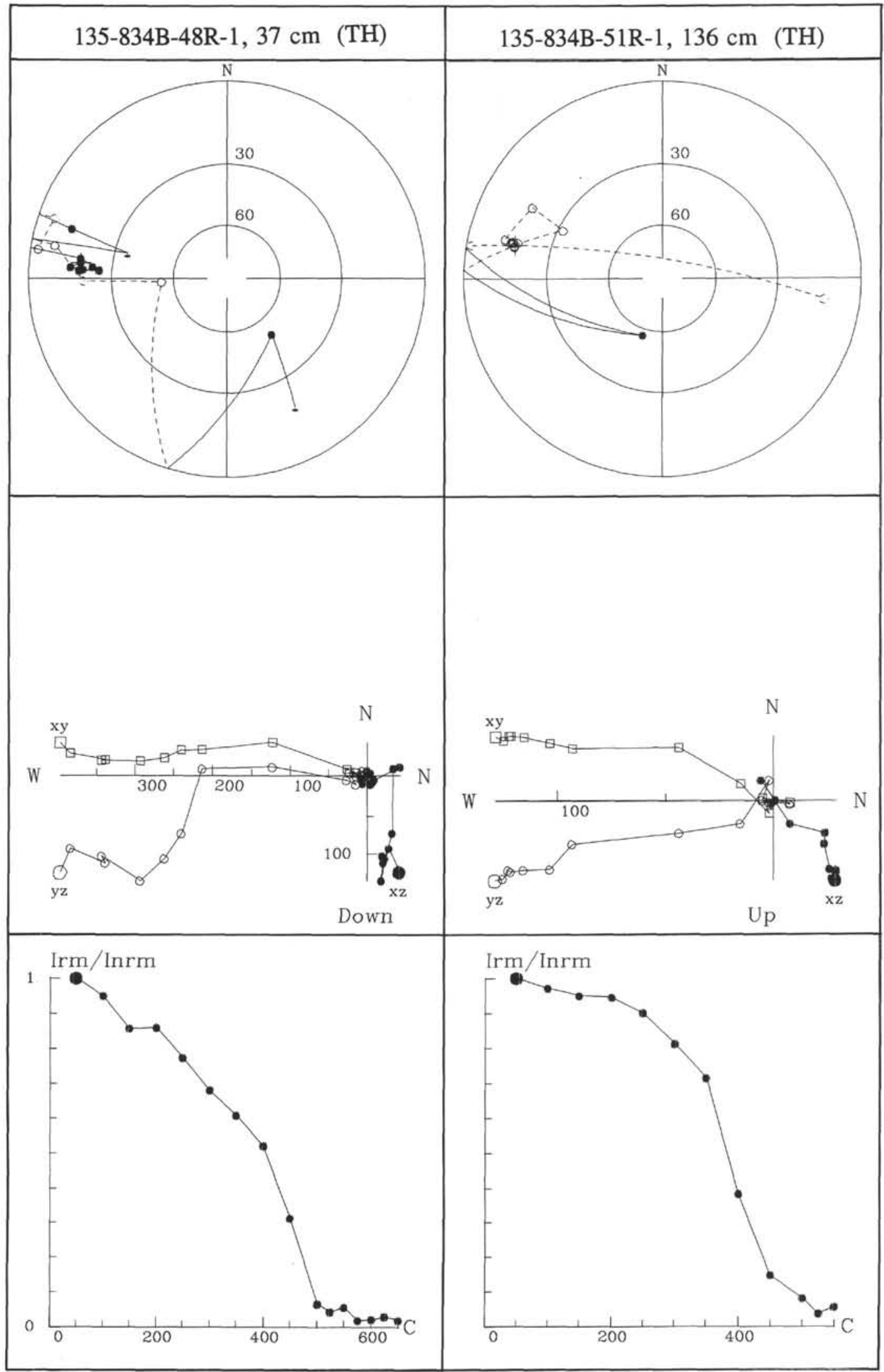

Figure 3 (continued). 


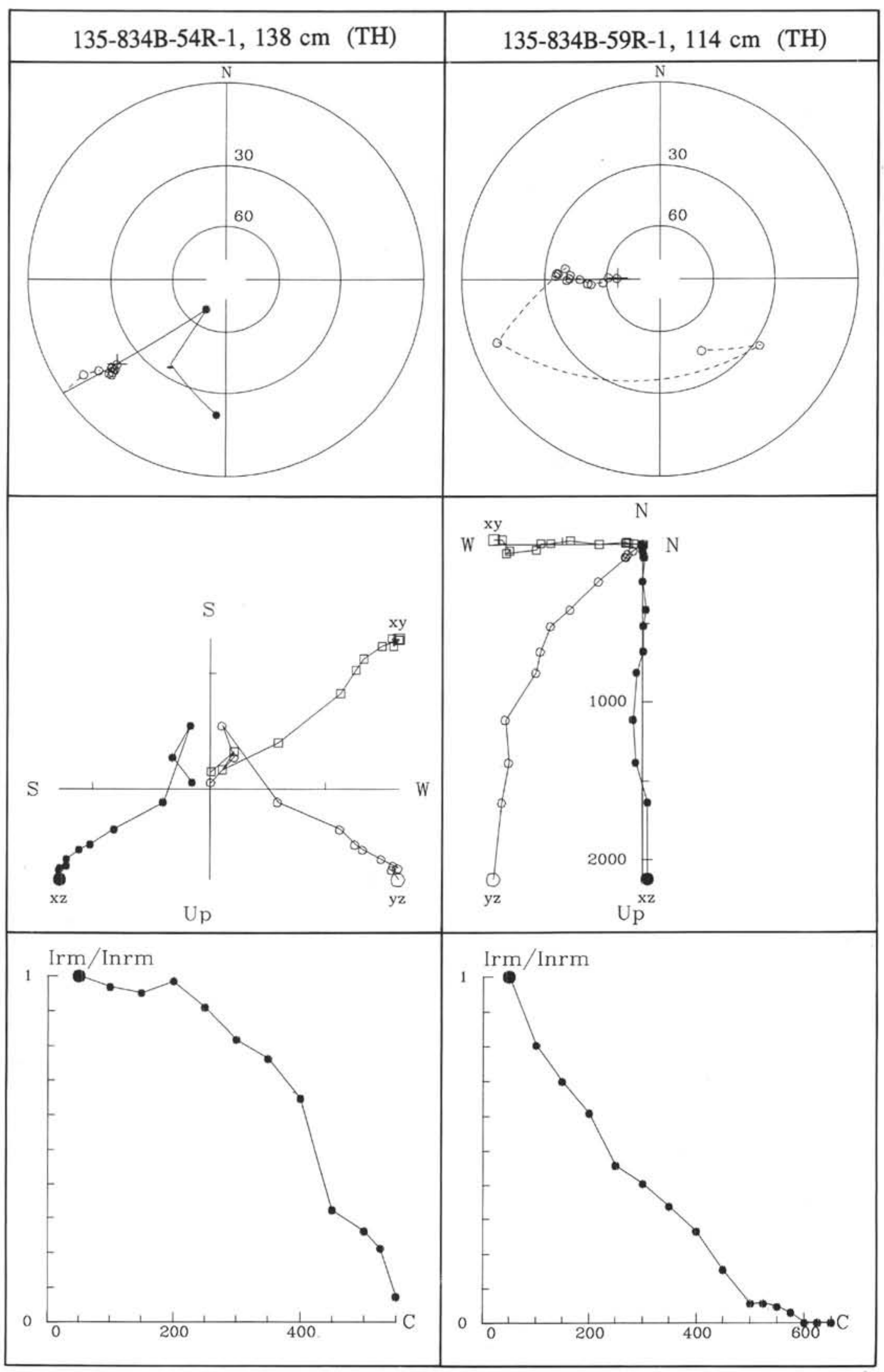

Figure 3 (continued). 


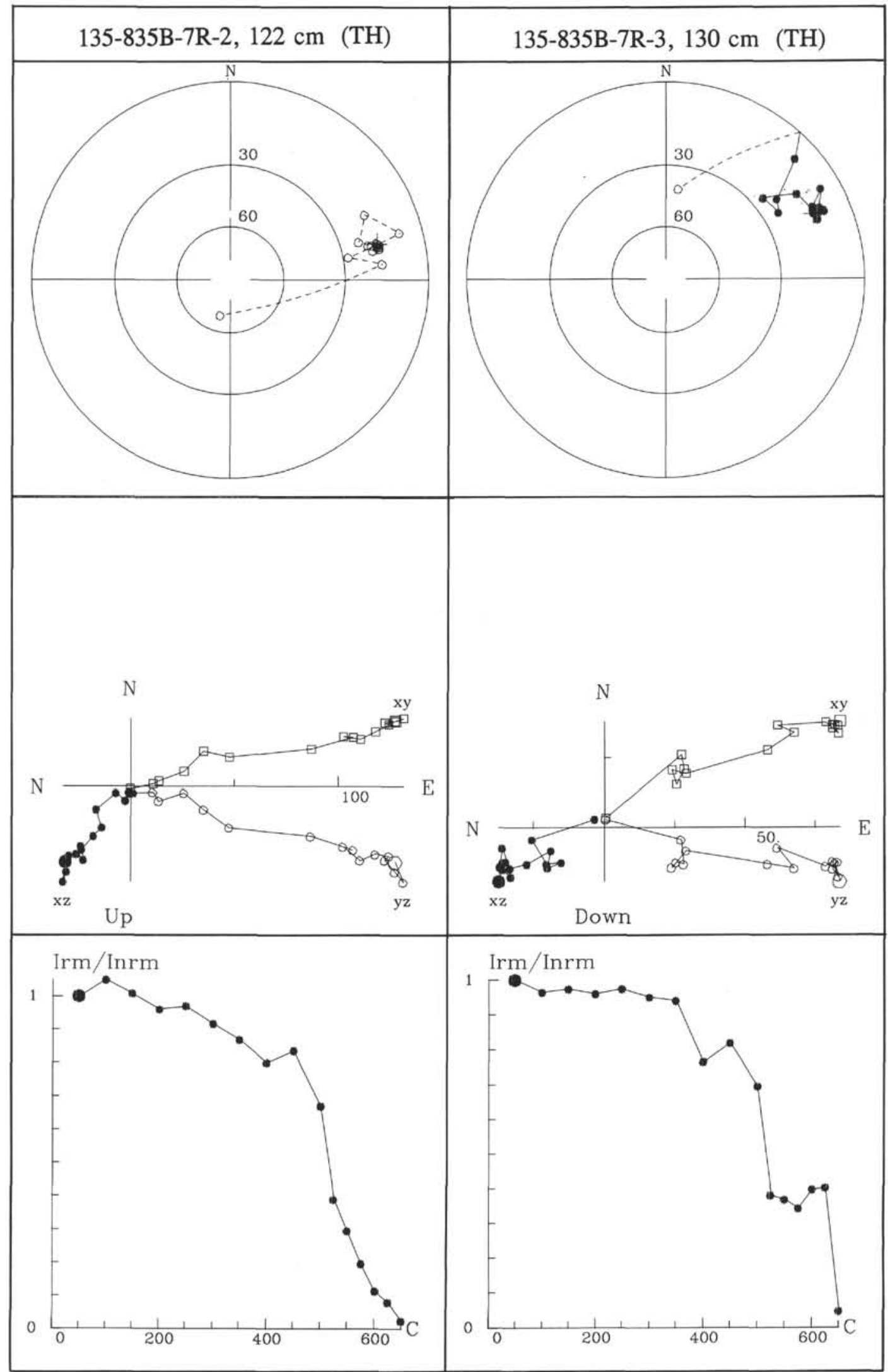

Figure 3 (continued). 


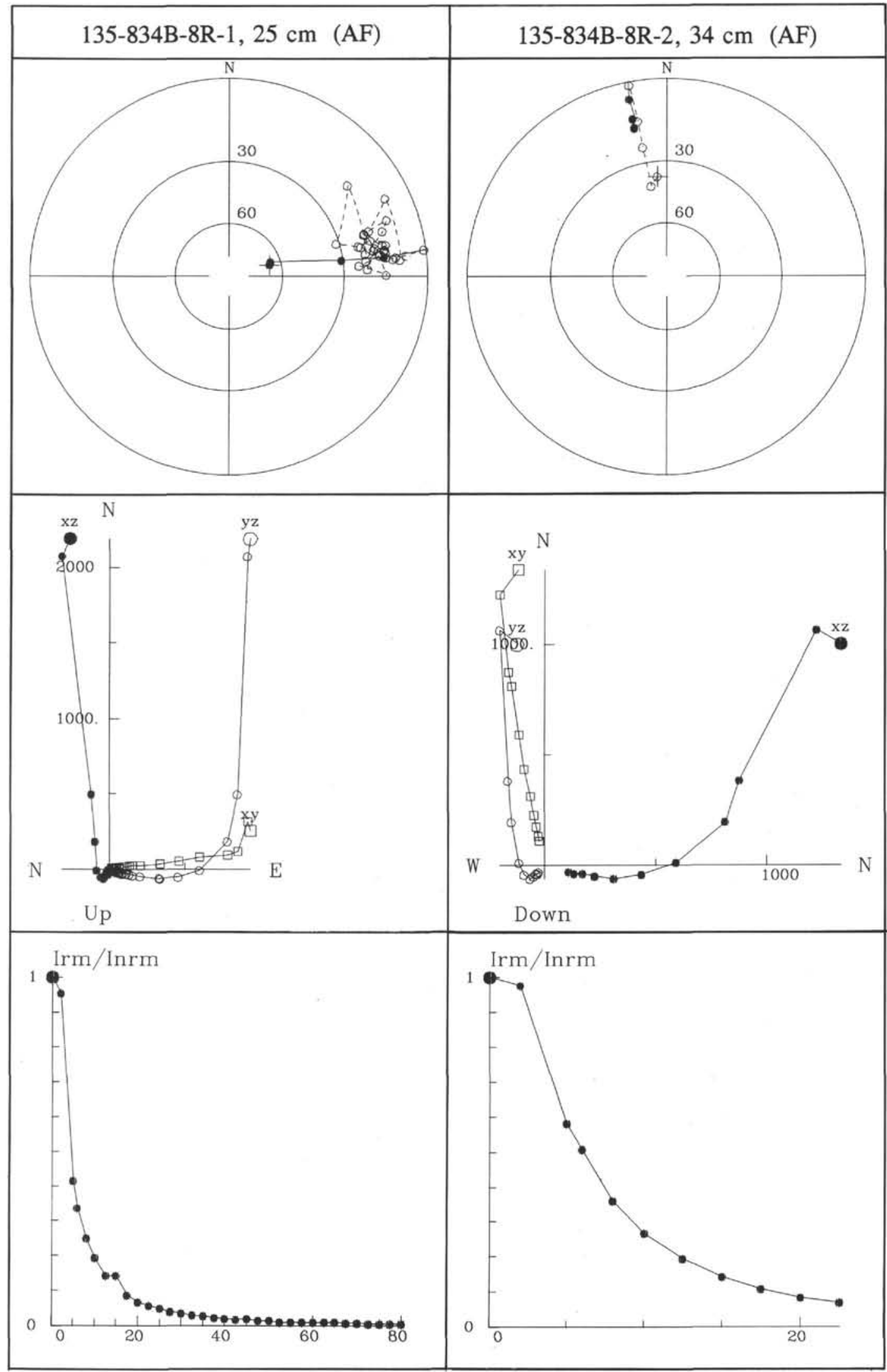

Figure 4. Alternating-field (AF) demagnetization of 11 basalt samples from Hole 834B. Stereograms (top), orthogonal plots (middle part), and intensity-decay curves (base) are illustrated. 


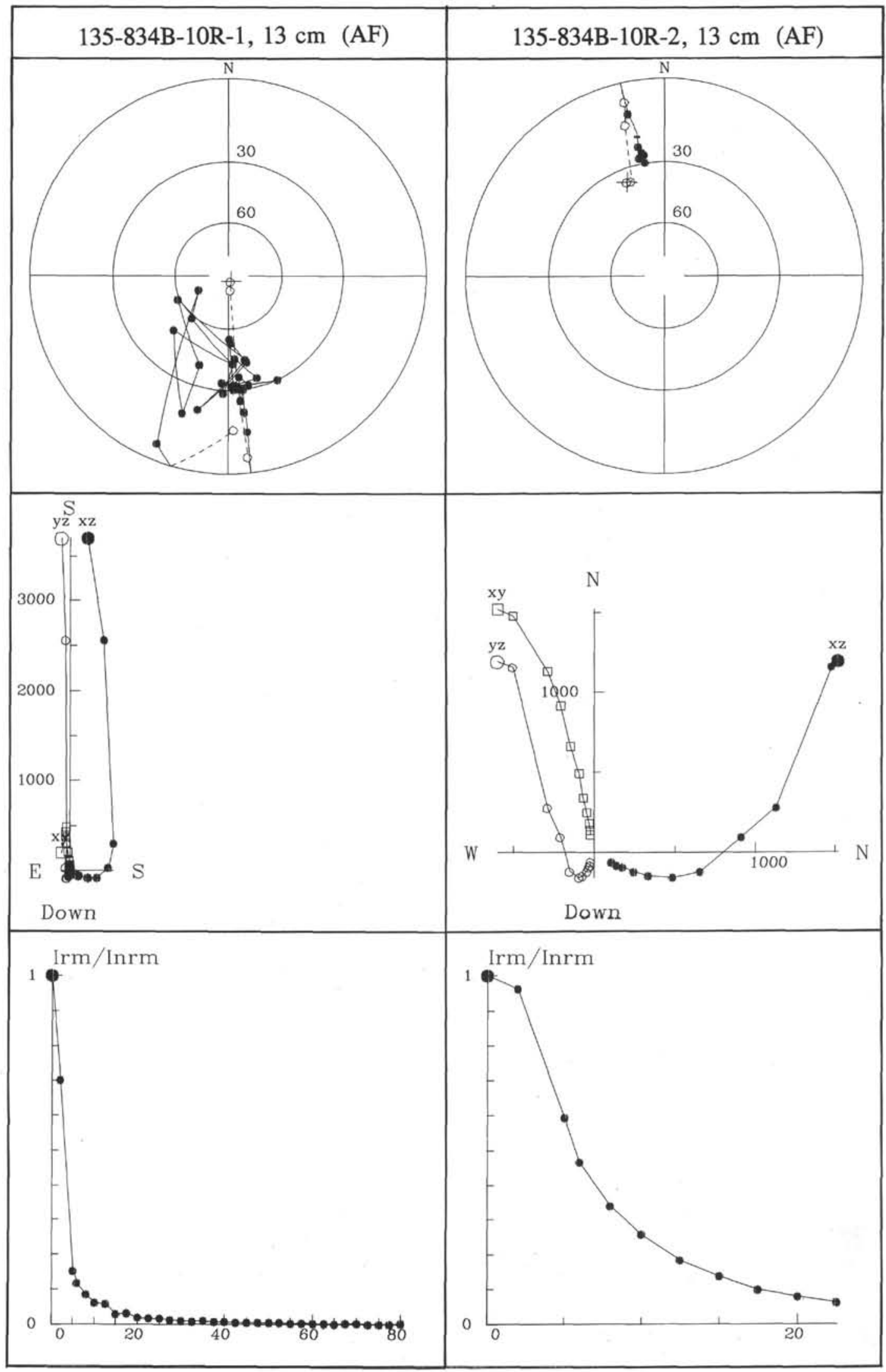

Figure 4 (continued). 


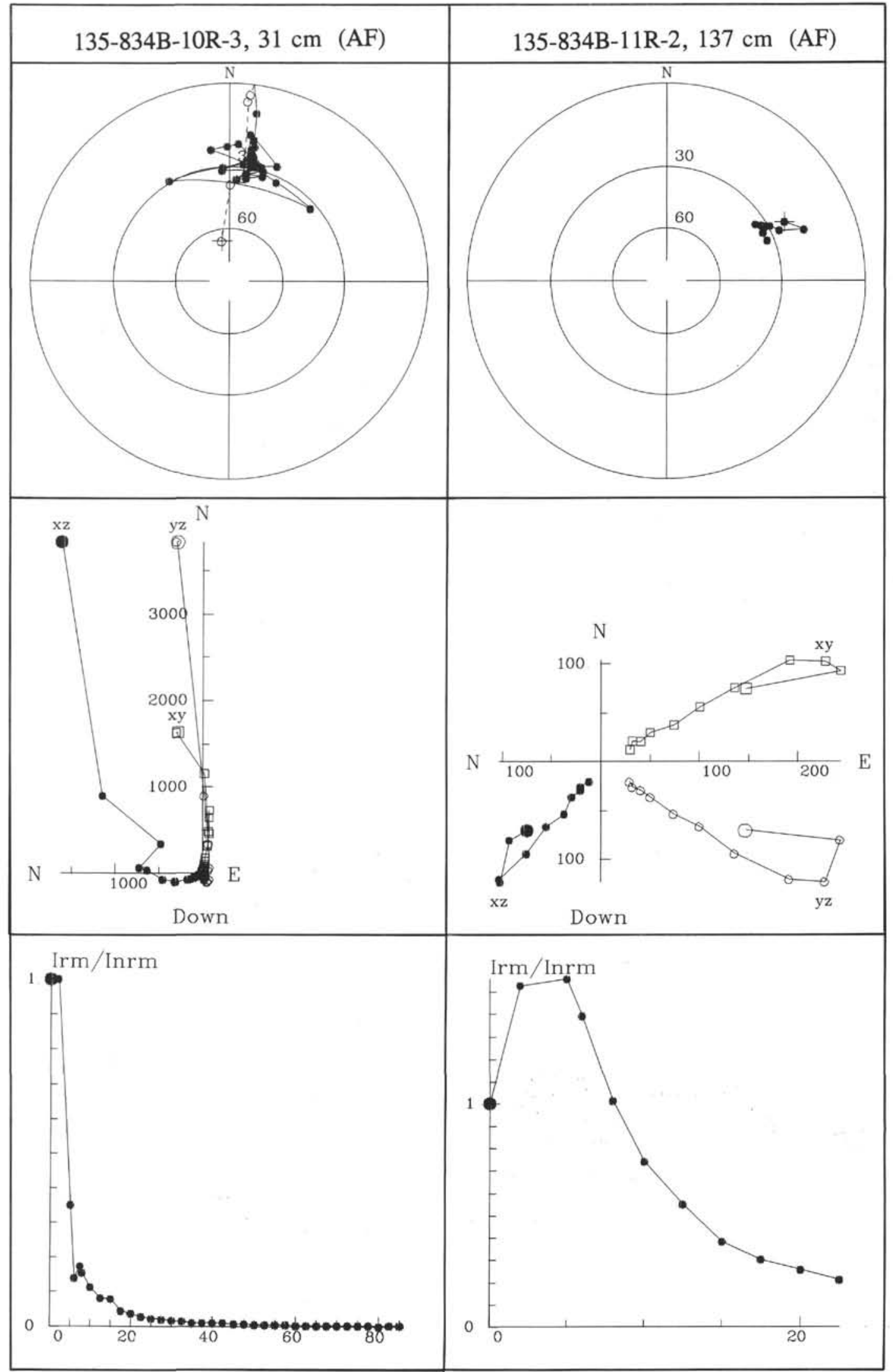

Figure 4 (continued). 


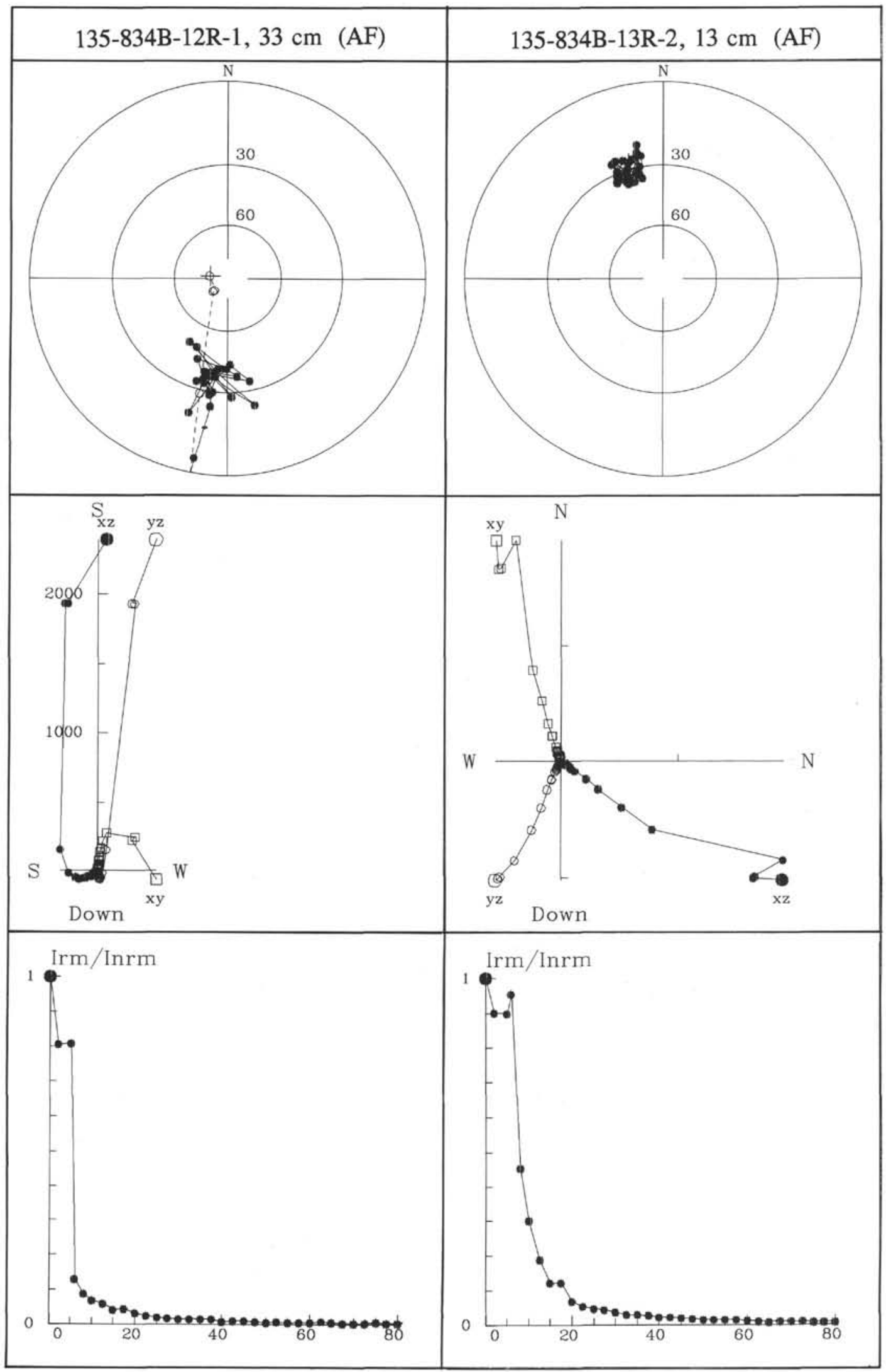

Figure 4 (continued). 


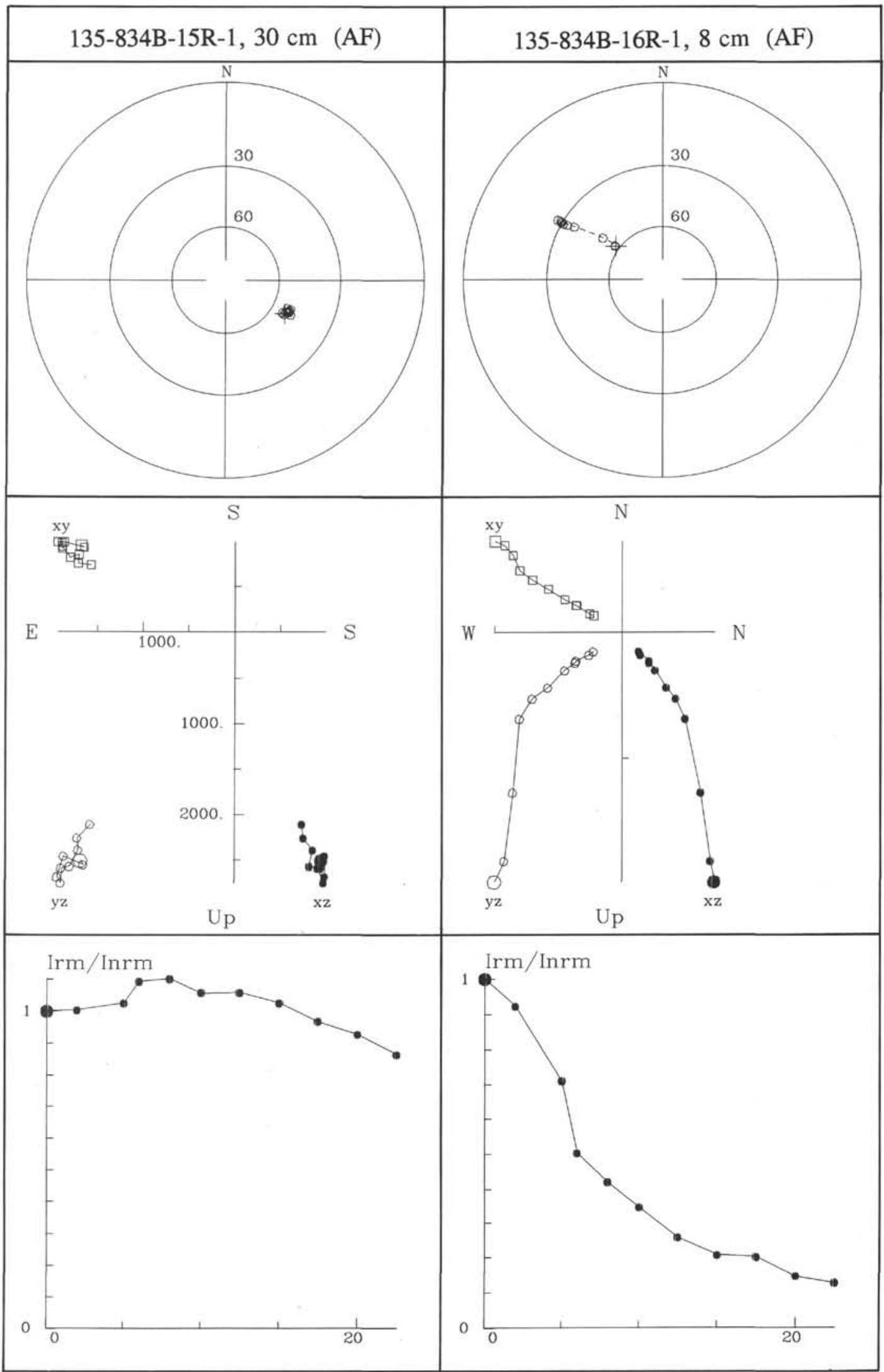

Figure 4 (continued). 


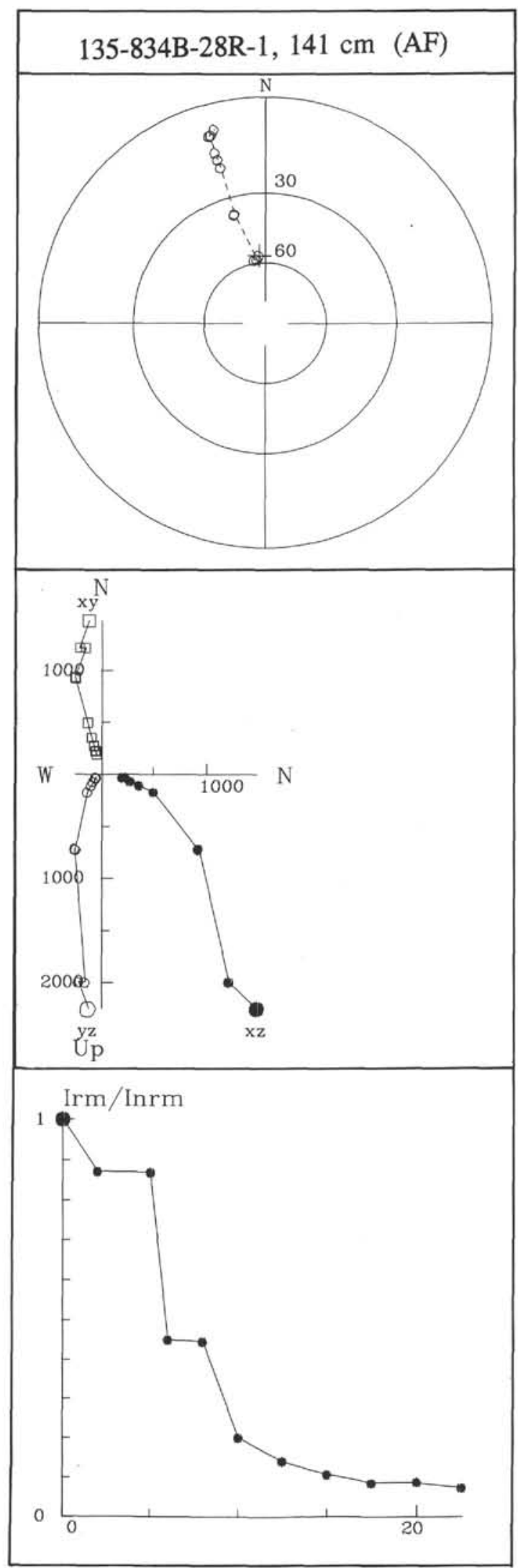

Figure 4 (continued). 


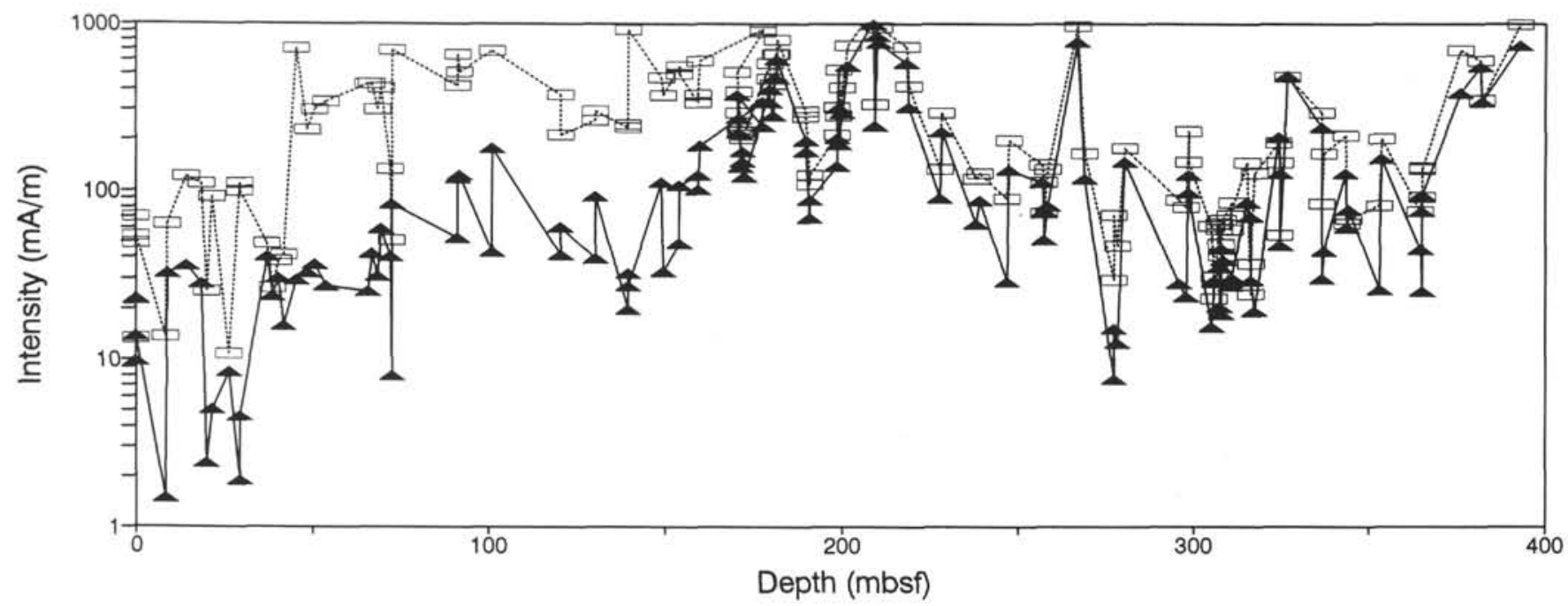

Figure 5. Remanent intensity of sediment cubes from Holes $841 \mathrm{~A}$ and $841 \mathrm{~B}$ before (open symbols) and after (solid symbols) 20-mT AF demagnetization. Above $170 \mathrm{mbsf}$ the decrease in intensity is as high as a factor of 10 , whereas below $170 \mathrm{mbsf}$ the decrease in intensity is only $20 \%$ to $50 \%$.

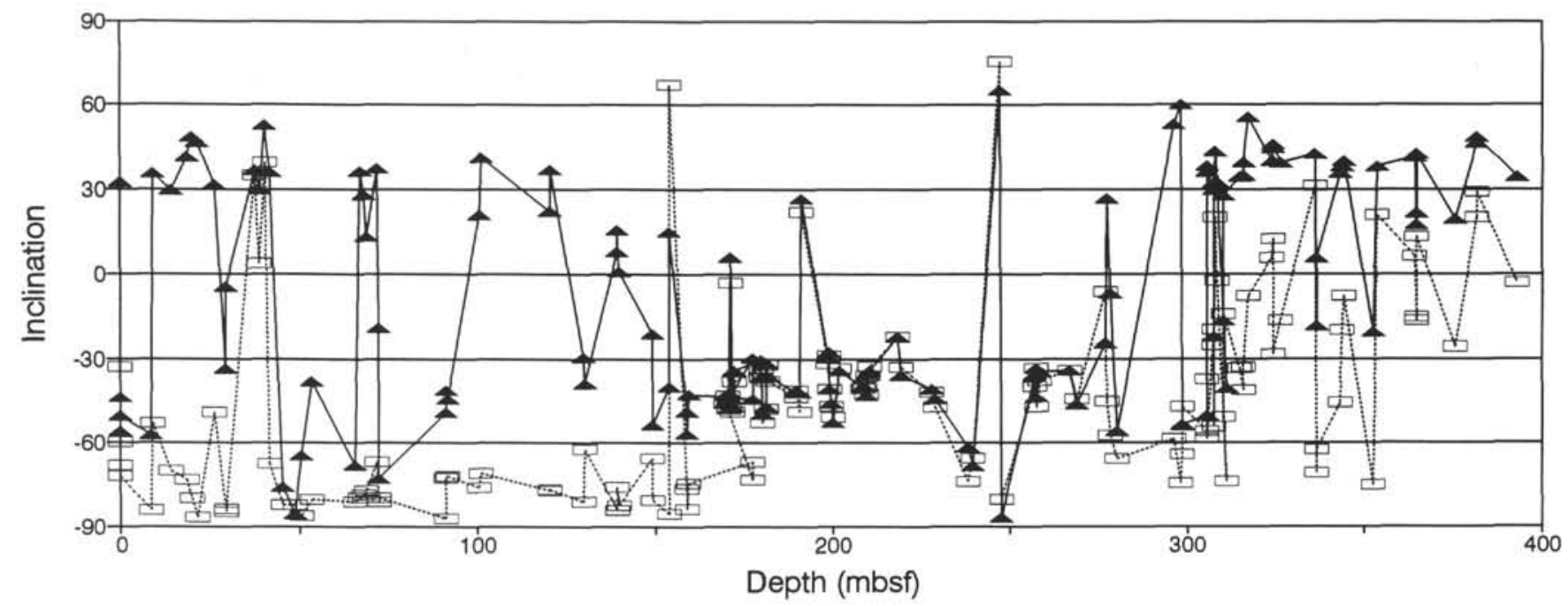

Figure 6. Inclination of sediment cubes from Holes 841A and 841B before (open symbols) and after (solid symbols) 20-mT AF demagnetization. Above 170 mbsf the NRM inclination is steeply negative because of the dominant drill-string-induced magnetization. Below 170 mbsf the drill-string-induced magnetization is much less dominant. 
Table 2. Inclination and intensity of sediments from Holes $841 \mathrm{~A}$ and $841 \mathrm{~B}$, before ([INRM] and $\left.\left[\mathrm{J}_{\mathrm{NRM}}\right]\right)$ and after $\left(\left[\mathrm{I}_{20}\right]\right.$ and $\left.\left[\mathrm{J}_{20}\right]\right) 20$-mT alternating-field cleaning.

\begin{tabular}{|c|c|c|c|c|}
\hline $\begin{array}{l}\text { Core, section, } \\
\text { interval }(\mathrm{cm})\end{array}$ & $\begin{array}{l}\text { Depth } \\
\text { (mbsf) }\end{array}$ & $\begin{array}{c}\mathrm{J}_{\mathrm{NRM}} \\
(\mathrm{mA} / \mathrm{m})\end{array}$ & $\mathrm{I}_{20}(\mathrm{o})$ & $\mathrm{J}_{20}(\mathrm{~mA} / \mathrm{m})$ \\
\hline \multicolumn{5}{|l|}{$135-841 \mathrm{~A}-$} \\
\hline $1 \mathrm{H}-1,14$ & $0.14-32.9$ & 13.3 & 32.4 & 9.7 \\
\hline $1 \mathrm{H}-1,20$ & $0.20-59.7$ & 48.7 & -43.7 & 22.7 \\
\hline $1 \mathrm{H}-1,30$ & $0.30-68.2$ & 70.1 & -55.9 & 22.5 \\
\hline $1 \mathrm{H}-1,40$ & $0.40-72.0$ & $54.3-$ & -50.3 & 13.8 \\
\hline $2 \mathrm{H}-1,28$ & $8.80-84.1$ & 13.7 & -57.1 & 1.5 \\
\hline $2 \mathrm{H}-1.70$ & $9.20-53.0$ & 63.6 & 35.8 & 32.1 \\
\hline $2 \mathrm{H}-4,70$ & $14.20-69.9$ & 121.6 & 29.5 & 35.8 \\
\hline $3 \mathrm{H}-1,50$ & $18.50-73.2$ & 110.6 & 41.6 & 28.0 \\
\hline $3 \mathrm{H}-2,50$ & $20.00-79.8$ & 25.2 & 48.6 & 2.4 \\
\hline $3 \mathrm{H}-3,50$ & $21.50-86.7$ & 91.5 & 46.6 & 5.0 \\
\hline $3 \mathrm{H}-6,60$ & $26.10-49.2$ & 10.8 & 31.5 & 8.4 \\
\hline $4 \mathrm{H}-2,30$ & $29.30-83.8$ & 110.6 & -33.6 & 1.9 \\
\hline $4 \mathrm{H}-2,50$ & $29.50-84.8$ & 98.8 & -4.8 & 4.6 \\
\hline $5 \mathrm{H}-1,40$ & $37.40 \quad 35.0$ & 48.8 & 36.7 & 40.8 \\
\hline $5 \mathrm{H}-2,40$ & $38.90 \quad 3.6$ & 26.4 & 29.9 & 23.6 \\
\hline $5 \mathrm{H}-3,40$ & $40.40 \quad 39.7$ & 38.4 & 52.6 & 30.4 \\
\hline $5 \mathrm{H}-4,40$ & $41.90-67.3$ & 41.8 & 36.1 & 15.7 \\
\hline $5 \mathrm{H}-6,80$ & $45.30-82.2$ & 704.3 & -75.8 & 29.7 \\
\hline $6 \mathrm{H}-2,79$ & $48.79-82.0$ & 228.0 & -85.8 & 32.7 \\
\hline $6 \mathrm{H}-3,110$ & $50.60-86.1$ & 303.1 & -64.4 & 36.2 \\
\hline $6 \mathrm{H}-5,110$ & $53.60-80.3$ & 335.6 & -37.9 & 27.2 \\
\hline $8 \mathrm{H}-1,22$ & $65.72-81.2$ & 432.9 & -68.2 & 25.3 \\
\hline $8 \mathrm{H}-1,142$ & $66.92-79.7$ & 433.4 & 36.2 & 42.3 \\
\hline $8 \mathrm{H}-2,80$ & $68.30-78.5$ & 303.0 & 27.9 & 30.9 \\
\hline $8 \mathrm{H}-3,70$ & $69.20-77.0$ & 405.5 & 13.3 & 59.2 \\
\hline $9 X-1,16$ & $71.86-66.8$ & 134.6 & 37.2 & 40.5 \\
\hline $9 \mathrm{X}-1,59$ & $72.29-81.2$ & 50.5 & -18.9 & 8.0 \\
\hline $9 X-1,62$ & $72.32-79.7$ & 690.9 & -73.0 & 82.9 \\
\hline $11 X-1,24$ & $91.24-87.2$ & 419.2 & -49.1 & 52.8 \\
\hline $11 X-1,36$ & $91.36-72.7$ & 645,1 & -41.3 & 118.4 \\
\hline $11 X-1,48$ & $91.48-71.9$ & 506.1 & -44.2 & 123.2 \\
\hline $12 X-?, 9$ & $100.79-76.1$ & 679.2 & 21.0 & 43.5 \\
\hline $12 \mathrm{X}-?, 15$ & $100.85-71.1$ & 678.2 & 41.2 & 178.0 \\
\hline $14 \mathrm{X}-1,33$ & $120.33-77.0$ & 373.0 & 22.1 & 41.9 \\
\hline $14 X-1,49$ & $120.49-76.6$ & 214.8 & 37.0 & 60.9 \\
\hline $15 \mathrm{X}-1,38$ & $129.98-81.2$ & 259.6 & -29.3 & 39.9 \\
\hline $15 X-1,76$ & $130.36-62.4$ & 297.6 & -38.8 & 92.5 \\
\hline $16 X-1,8$ & $139.38-84.2$ & 237.4 & & 7.9 \\
\hline $16 \mathrm{X}-1,13$ & $139.43-75.6$ & 244.8 & 15.4 & 32.3 \\
\hline $16 \mathrm{X}-1,20$ & $139.50-82.6$ & 912.4 & & 0.8 \\
\hline $17 X-1,6$ & $148.96-65.6$ & 467.3 & -21.2 & 111.8 \\
\hline $17 \mathrm{X}-1,30$ & $149.20-80.7$ & 365.6 & -53.6 & 33.1 \\
\hline $18 X-1,6$ & $153.96-85.4$ & 548.3 & -39.8 & 49.1 \\
\hline $18 X-1,9$ & $153.99 \quad 67.2$ & 496.3 & 15.0 & 108.0 \\
\hline $19 X-1,2$ & $159.12-76.4$ & 333.9 & -48.9 & 123.2 \\
\hline $19 X-1,12$ & $159.22-83.7$ & 370.3 & -56.7 & 101.4 \\
\hline $19 \times-1,42$ & $159.52-74.4$ & 596.2 & -42.9 & 185.3 \\
\hline $21 X-1,33$ & $177.23-66.8$ & 926.9 & -44.2 & 337.7 \\
\hline $21 X-1,47$ & $177.37-73.2$ & 889.0 & -29.5 & 238.3 \\
\hline
\end{tabular}

135-841B-

\begin{tabular}{|c|c|c|c|c|}
\hline $2 \mathrm{R}-1,21$ & $170.01-46.0$ & 504.7 & -45.9 & 367.4 \\
\hline $2 \mathrm{R}-1,66$ & $170.46-43.2$ & 290.2 & -43.5 & 220.4 \\
\hline $2 \mathrm{R}-1,110$ & $170.9-47.9$ & 387.7 & -42.5 & 265.8 \\
\hline 2R-1, 116 & $170.96-47.2$ & 223.6 & -42.2 & 137.1 \\
\hline $2 \mathrm{R}-2,15$ & $\begin{array}{ll}171.45 & -3.0\end{array}$ & 203.6 & 5.8 & 148.7 \\
\hline $2 \mathrm{R}-2,63$ & $171.93-48.7$ & 222.8 & -47.2 & 168.5 \\
\hline $2 \mathrm{R}-2,93$ & $172.2-37.9$ & 213.9 & -34.0 & 119.6 \\
\hline $3 R-1,16$ & $179.56-33.5$ & 569.8 & -30.3 & 399.8 \\
\hline $3 \mathrm{R}-1,24$ & $179.64-36.5$ & 464.5 & -36.6 & 333.6 \\
\hline $3 R-1,100$ & $180.4-52.6$ & 428.7 & -49.8 & 278.0 \\
\hline $3 R-2,6$ & $180.96-47.8$ & 647.3 & -47.2 & 467.1 \\
\hline $3 R-2,42$ & $181.32-31.9$ & 655.0 & -31.1 & 461.8 \\
\hline $3 \mathrm{R}-2,54$ & $181.44-37.5$ & 797.8 & -36.1 & 598.9 \\
\hline $4 \mathrm{R}-1,67$ & $189.77-43.6$ & 292.7 & -42.1 & 196.4 \\
\hline $4 \mathrm{R}-1,72$ & $189.82-41.2$ & 273.1 & -41.2 & 169.8 \\
\hline $4 \mathrm{R}-2,13$ & $190.73-48.7$ & 108.7 & -42.0 & 69.1 \\
\hline $4 \mathrm{R}-2,55$ & $\begin{array}{ll}191.05 & 21.8\end{array}$ & 123.0 & 26.7 & 88.5 \\
\hline $5 R-1,9$ & $198.79-31.7$ & 214.0 & -29.6 & 139.2 \\
\hline
\end{tabular}

\begin{tabular}{|c|c|c|c|c|c|}
\hline $\begin{array}{l}\text { Core, section, } \\
\text { interval }(\mathrm{cm})\end{array}$ & $\begin{array}{l}\text { Depth } \\
\text { (mbsf) }\end{array}$ & $\begin{array}{l}\mathrm{I}_{\mathrm{NRM}} \\
\text { (o) }\end{array}$ & $\begin{array}{c}\mathrm{J}_{\mathrm{NRM}} \\
(\mathrm{mA} / \mathrm{m})\end{array}$ & $\mathrm{I}_{20}(\mathrm{o})$ & $\mathrm{J}_{20}(\mathrm{~mA} / \mathrm{m})$ \\
\hline $5 \mathrm{R}-1,15$ & 198.85 & -28.6 & 311.6 & -27.3 & 202.9 \\
\hline $5 \mathrm{R}-1,37$ & 199.07 & -40.8 & 526.9 & -40.9 & 310.3 \\
\hline $5 \mathrm{R}-2,15$ & 199.35 & -46.8 & 277.3 & -45.9 & 187.2 \\
\hline $5 R-2,86$ & 200.06 & -50.9 & 408.7 & -52.7 & 286.8 \\
\hline $5 R-3,6$ & 201.76 & -33.0 & 733.4 & -34.2 & 550.5 \\
\hline $6 \mathrm{R}-1,17$ & 208.57 & -40.5 & 1223.3 & -39.9 & 1024.0 \\
\hline $6 \mathrm{R}-1,71$ & 209.11 & -39.8 & 1205.8 & -39.8 & 976.9 \\
\hline $6 \mathrm{R}-1,109$ & 209.49 & -42.5 & 323.1 & -43.0 & 241.3 \\
\hline $6 \mathrm{R}-2,8$ & 209.98 & -35.6 & 1074.6 & -35.1 & 839.1 \\
\hline $6 \mathrm{R}-2,63$ & 210.53 & -32.6 & 946.7 & -34.0 & 758.9 \\
\hline $7 \mathrm{R}-1,23$ & 218.33 & -22.1 & 720.4 & -22.1 & 573.6 \\
\hline $7 \mathrm{R}-1,103$ & 219.13 & -32.9 & 416.6 & -35.8 & 311.3 \\
\hline $8 \mathrm{R}-1,11$ & 227.81 & -41.8 & 134.4 & -40.9 & 90.2 \\
\hline $8 \mathrm{R}-2,21$ & 228.51 & -47.3 & 289.0 & -44.3 & 223.1 \\
\hline $9 \mathrm{R}-1,65$ & 238.05 & -73.8 & 117.8 & -61.6 & 63.5 \\
\hline $9 R-2,36$ & 239.36 & -65.4 & 126.0 & -68.4 & 87.5 \\
\hline $10 \mathrm{R}-1,3$ & 247.03 & 75.3 & 88.9 & 65.3 & 29.0 \\
\hline $10 \mathrm{R}-1,62$ & 247.62 & -80.2 & 198.3 & -86.6 & 132.9 \\
\hline $11 \mathrm{R}-1,10$ & 256.8 & -40.0 & 142.7 & -35.6 & 111.5 \\
\hline $11 \mathrm{R}-2,10$ & 257.3 & -33.3 & 113.2 & -33.2 & 75.4 \\
\hline $11 \mathrm{R}-2,42$ & 257.62 & -47.1 & 74.0 & -43.7 & 51.3 \\
\hline $11 \mathrm{R}-2,102$ & 258.22 & -37.7 & 134.6 . & -34.3 & 81.1 \\
\hline $12 \mathrm{R}-1,46$ & 266.96 & -34.1 & 957.4 & -34.2 & 770.2 \\
\hline $12 \mathrm{R}-2,84$ & 268.64 & -44.5 & 165.1 & -46.2 & 117.4 \\
\hline $13 \mathrm{R}-1,135$ & 276.95 & -6.1 & 29.7 & -24.5 & 7.7 \\
\hline $13 R-2,6$ & 277.16 & -45.3 & 71.6 & 26.7 & 15.2 \\
\hline $13 \mathrm{R}-2,124$ & 278.34 & -57.5 & 47.2 & -6.8 & 12.6 \\
\hline $13 \mathrm{R}-4,4$ & 280.14 & -65.9 & 178.3 & -55.9 & 147.2 \\
\hline $15 \mathrm{R}-1,104$ & 295.94 & -58.7 & 88.3 & 53.0 & 28.3 \\
\hline $15 \mathrm{R}-3,1$ & 297.91 & -74.4 & 80.5 & 59.9 & 23.3 \\
\hline $15 \mathrm{R}-3,38$ & 298.28 & -64.3 & 224.6 & -53.9 & 123.2 \\
\hline $15 \mathrm{R}-3,73$ & 298.63 & -47.4 & 147.9 & -53.7 & 96.9 \\
\hline $16 \mathrm{R}-1,78$ & 305.38 & -56.0 & 62.1 & -50.3 & 15.6 \\
\hline $16 \mathrm{R}-1,98$ & 305.58 & -37.4 & 22.8 & 38.4 & 29.2 \\
\hline $16 \mathrm{R}-1,110$ & 305.7 & -58.3 & 30.6 & 35.9 & 28.7 \\
\hline $16 \mathrm{R}-2,124$ & 307.34 & -19.6 & 59.6 & 29.5 & 34.9 \\
\hline $16 \mathrm{R}-2,138$ & 307.48 & -54.4 & 63.9 & -22.3 & 20.3 \\
\hline $16 \mathrm{R}-3,2$ & 307.62 & -25.2 & 41.2 & 32.3 & 18.6 \\
\hline $16 \mathrm{R}-3,29$ & 307.89 & 20.1 & 48.3 & 43.4 & 45.6 \\
\hline $16 \mathrm{R}-3,53$ & 308.13 & -2.3 & 67.4 & 32.6 & 38.9 \\
\hline $16 R-5,37$ & 310.97 & -73.8 & 84.6 & -40.5 & 30.3 \\
\hline $16 \mathrm{R}-5,61$ & 310.21 & -50.7 & 59.0 & -16.6 & 27.0 \\
\hline $16 \mathrm{R}-5,84$ & 310.44 & -14.1 & 71.6 & 27.7 & 28.4 \\
\hline $17 \mathrm{R}-1,102$ & 314.82 & -33.3 & 146.2 & 34.3 & 84.9 \\
\hline $17 R-2,68$ & 315.98 & -41.0 & 24.3 & 34.6 & 70.2 \\
\hline $17 \mathrm{R}-2,83$ & 316.13 & -32.7 & 37.0 & 39.4 & 29.0 \\
\hline $17 \mathrm{R}-3,32$ & 317.12 & -7.7 & 125.9 & 55.5 & 19.1 \\
\hline $18 \mathrm{R}-1,31$ & 323.81 & 5.7 & 191.6 & 40.0 & 207.0 \\
\hline $18 \mathrm{R}-1,105$ & 324.55 & 12.3 & 145.5 & 44.5 & 125.9 \\
\hline $18 \mathrm{R}-1,109$ & 324.59 & -28.3 & 54.7 & 45.7 & 47.9 \\
\hline $18 \mathrm{R}-2,126$ & 326.26 & -16.4 & 473.9 & 39.1 & 480.7 \\
\hline $19 \mathrm{R}-3,8$ & 336.28 & 31.3 & 291.0 & 42.4 & 235.1 \\
\hline $19 \mathrm{R}-3,34$ & 336.54 & -70.8 & 84.5 & -18.5 & 30.0 \\
\hline $19 \mathrm{R}-3,55$ & 336.75 & -62.5 & 166.1 & & 5.6 \\
\hline $20 \mathrm{R}-1,78$ & 343.28 & -45.5 & 211.0 & 35.7 & 126.1 \\
\hline $20 \mathrm{R}-1,110$ & 343.6 & -19.9 & 64.4 & 38.0 & 60.3 \\
\hline $20 \mathrm{R}-2,12$ & 344.12 & -8.0 & 68.4 & 39.8 & 76.6 \\
\hline $21 \mathrm{R}-1,76$ & 252.86 & -75.1 & 81.7 & -20.7 & 25.7 \\
\hline $21 \mathrm{R}-2,2$ & 353.62 & 21.1 & 204.8 & 37.9 & 154.5 \\
\hline $22 \mathrm{R}-3,26$ & 364.66 & 6.4 & 74.9 & 41.5 & 44.9 \\
\hline $22 \mathrm{R}-3,32$ & 364.72 & -15.1 & 91.3 & 17.3 & 25.2 \\
\hline $22 \mathrm{R}-3,47$ & 364.87 & -16.5 & 137.3 & 21.7 & 75.4 \\
\hline $22 \mathrm{R}-3,68$ & 365.08 & 13.3 & 134.0 & 42.5 & 93.3 \\
\hline $23 R-4,36$ & 375.96 & -25.7 & 683.5 & 19.3 & 379.5 \\
\hline $24 \mathrm{R}-1,96$ & 381.66 & 19.9 & 589.6 & 46.4 & 544.2 \\
\hline $24 \mathrm{R}-1,115$ & 381.85 & 28.9 & 346.7 & 48.5 & 336.6 \\
\hline $25 \mathrm{R}-2,112$ & 393.02 & -3.1 & 986.7 & 34.3 & 729.9 \\
\hline \multicolumn{6}{|c|}{$(\operatorname{Im}=38.4+1.4)$} \\
\hline
\end{tabular}

Note: $I_{m}$ is the mean of the numerical values of $I_{20}$. 


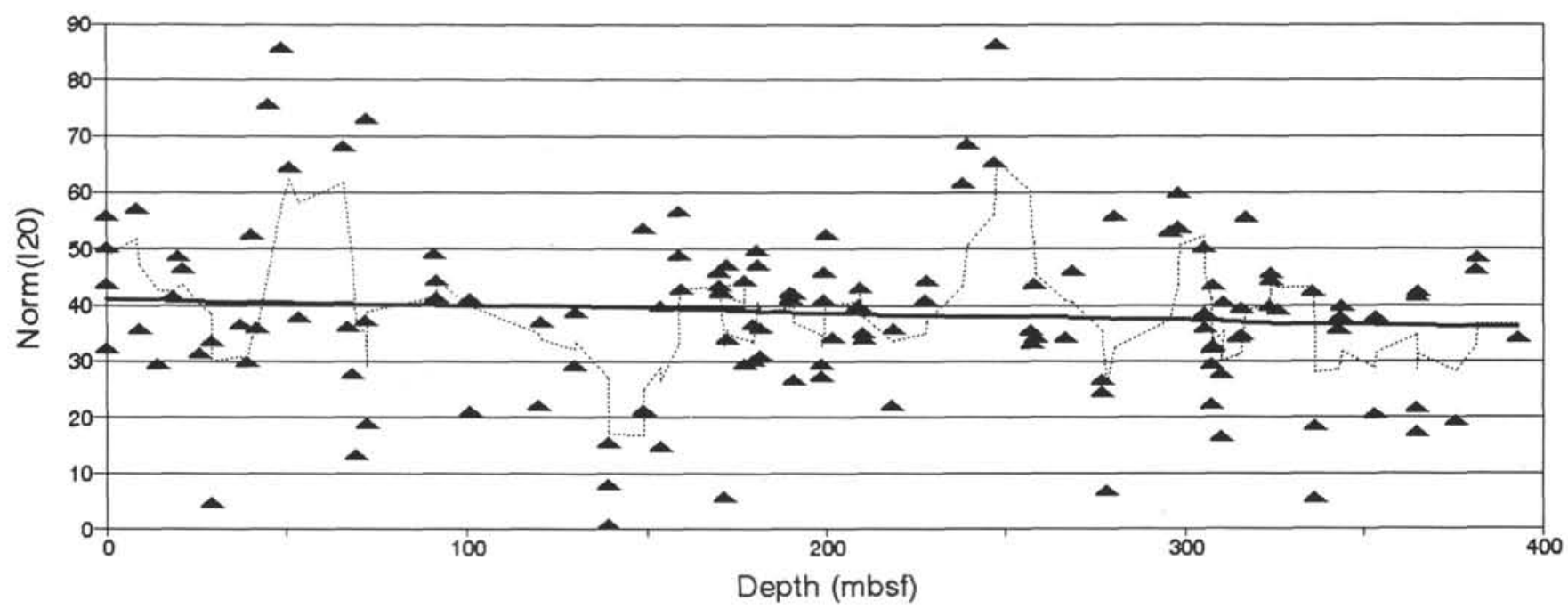

Figure 7. Stable inclinations $I_{20}$ (numerical values only; cf. Table 2) after partial AF cleaning in a 20-mT field of sediment cubes from Holes $841 \mathrm{~A}$ and $841 \mathrm{~B}$. Thin dotted line is a seven-point moving average. The thick solid line is the regression line: $\operatorname{Norm}\left(I_{20}\right)=-0.0145 \cdot \operatorname{Depth}+41.5(N=134)$. A systematic shallowing of the inclination depth of $1.5 \% 100 \mathrm{~m}$ is seen, although the scatter is high.

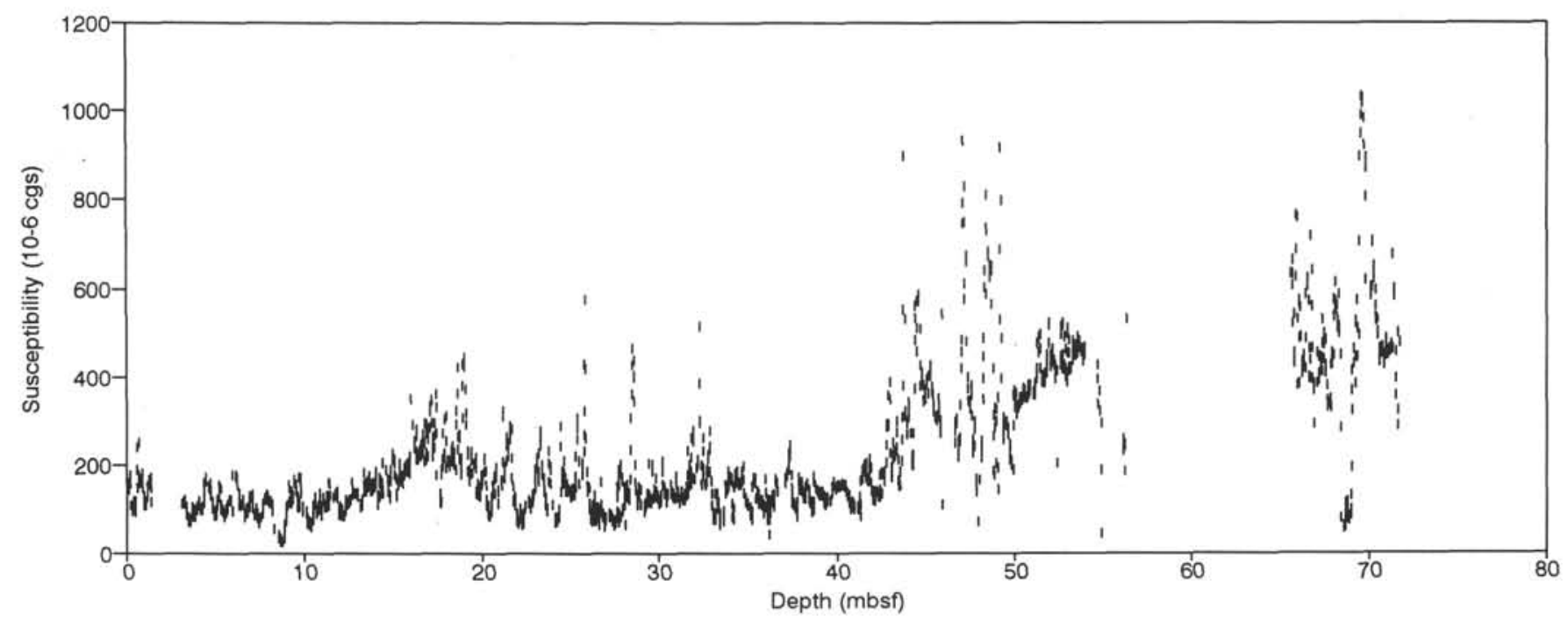

Figure 8. Whole-core magnetic volume susceptibility in sediments of Hole 841A. 


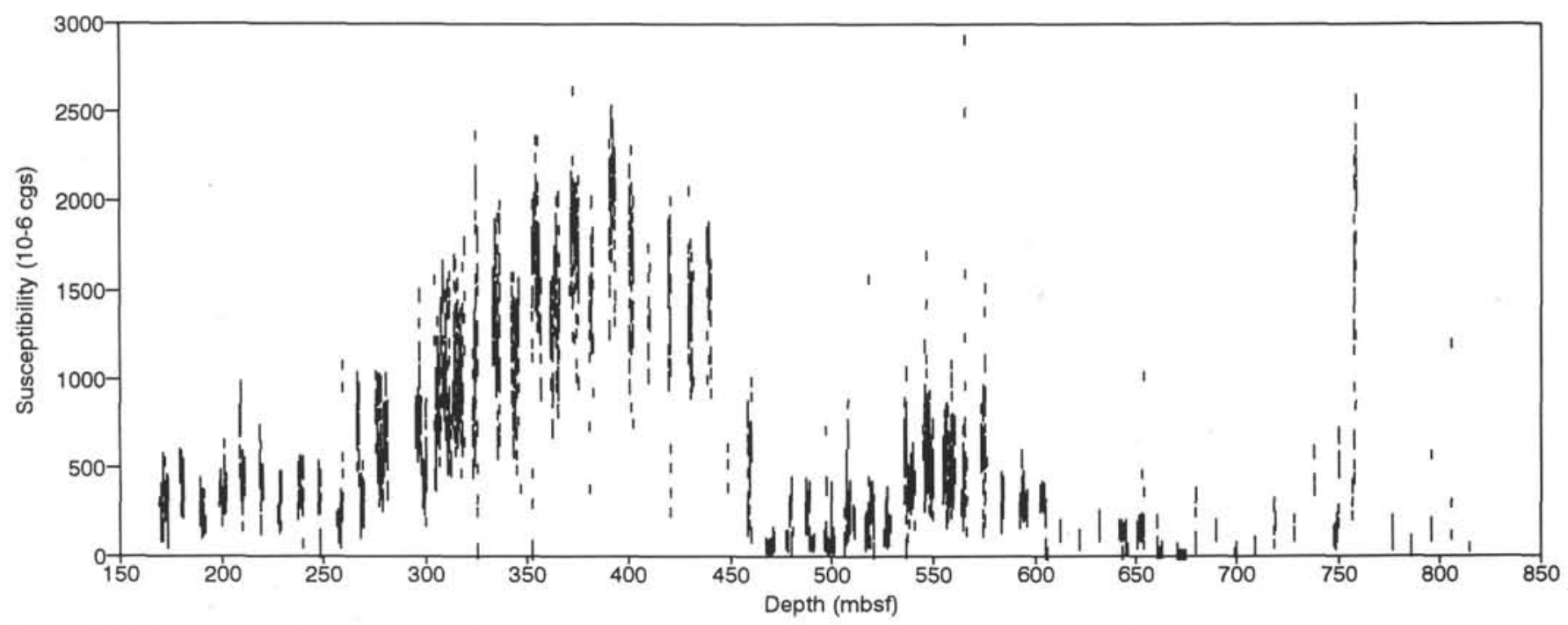

Figure 9. Whole-core magnetic volume susceptibility in sediments of Hole 841B. 